\title{
EPSL
}

Earth and Planetary Science Letters 210 (2003) 481-497

www.elsevier.com/locate/epsl

\section{Back-arc basin basalt systematics}

\author{
Brian Taylor ${ }^{\mathrm{a}, *}$, Fernando Martinez ${ }^{\mathrm{b}}$ \\ a Department of Geology and Geophysics, School of Ocean and Earth Science and Technology, University of Hawaii at Manoa, \\ Honolulu, HI 96822, USA \\ b Hawaii Institute of Geophysics and Planetology, School of Ocean and Earth Science and Technology, University of Hawaii at Manoa, \\ Honolulu, HI 96822, USA
}

Received 4 December 2002; received in revised form 14 March 2003; accepted 19 March 2003

\begin{abstract}
The Mariana, east Scotia, Lau, and Manus back-arc basins (BABs) have spreading rates that vary from slow $(<50$ $\mathrm{mm} / \mathrm{yr})$ to fast $(>100 \mathrm{~mm} / \mathrm{yr})$ and extension axes located from 10 to $400 \mathrm{~km}$ behind their island arcs. Axial lava compositions from these $\mathrm{BABs}$ indicate melting of mid-ocean ridge basalt (MORB)-like sources in proportion to the amount added of previously depleted, water-rich, arc-like components. The arc-like end-members are characterized by low $\mathrm{Na}$, Ti and $\mathrm{Fe}$, and by high $\mathrm{H}_{2} \mathrm{O}$ and $\mathrm{Ba} / \mathrm{La}$; the MORB-like end-members have the opposite traits. Comparisons between basins show that the least hydrous compositions follow global MORB systematics and an inverse correlation between $\mathrm{Na} 8$ and $\mathrm{Fe} 8$. This is interpreted as a positive correlation between the average degree and pressure of mantle melting that reflects regional variations in mantle potential temperatures (Lau/Manus hotter than Mariana/Scotia). This interpretation accords with numerical model predictions that faster subduction-induced advection will maintain a hotter mantle wedge. The primary compositional trends within each BAB (a positive correlation between $\mathrm{Fe} 8, \mathrm{Na} 8$ and Ti8, and their inverse correlation with $\mathrm{H}_{2} \mathrm{O}(8)$ and $\mathrm{Ba} / \mathrm{La}$ ) are controlled by variations in water content, melt extraction, and enrichments imposed by slab and mantle wedge processes. Systematic axial depth (as a proxy for crustal production) variations with distance from the island arc indicate that compositional controls on melting dominate over spreading rate. Hydrous fluxing enhances decompression melting, allowing depleted mantle sources just behind the island arc to melt extensively, producing shallow spreading axes. Flow of enriched mantle components around the ends of slabs may augment this process in transform-bounded back-arcs such as the east Scotia Basin. The re-circulation (by mantle wedge corner flow) to the spreading axes of mantle previously depleted by both arc and spreading melt extraction can explain the greater depths and thinner crust of the East Lau Spreading Center, Manus Southern Rifts, and Mariana Trough and the very depleted lavas of east Scotia segments E8/E9. The crust becomes mid-ocean ridge (MOR)-like where the spreading axes, further away from the island arc and subducted slab, entrain dominantly fertile mantle.
\end{abstract}

(C) 2003 Elsevier Science B.V. All rights reserved.

Keywords: Mariana Trough; Lau Basin; Manus Basin; east Scotia Basin; basalt; back-arc basin; mantle wedge; hydrous melt

\footnotetext{
* Corresponding author. Tel.: +1-808-956-6649; Fax: +1-808-956-3723.

E-mail address: taylorb@hawaii.edu (B. Taylor).
}

\section{Introduction}

Basalt geochemical data from the world's spreading centers reveal systematic correlations 
at both global and local scales related to the extent of mantle partial melting (e.g. [1]). At the global scale, the negative correlation of $\mathrm{Na}_{2} \mathrm{O}$ and $\mathrm{FeO}$ contents of mid-ocean ridge basalts (MORBs), fractionation-corrected to a common $8 \% \mathrm{MgO}(\mathrm{Na} 8, \mathrm{Fe} 8)$, reflects a positive correlation between the average degree and pressure of melting - as do $\mathrm{Ca}$ 8/A18 versus $\mathrm{Si} / \mathrm{Fe} 8$ ratios that correlates with regional increases in mantle potential temperatures [1-5]. At slow-spreading ridges, segment-scale compositional variations define local trends that are orthogonal to the global one $[3,4,6]$. Several possible causes for the local trends have been proposed [3,4,6-8], of which compositional heterogeneity and variable dynamics of melt supply are perhaps the most likely [9].

Although analyses of some basalts from backarc basin (BAB) spreading centers were included in the initial global compilations (e.g. Lau Basin, Mariana Trough and east Scotia Basin averages in $[1,2])$, the global compositional variation of $\mathrm{BAB}$ lavas has not been investigated previously. Basalts above subduction zones typically have higher oxygen fugacity $\left(f_{\mathrm{O} 2}\right)$ and water contents (e.g. [10-12]), and hence significant differences from MORB trends may be expected. Although MORB magmas are known to contain small amounts of water (e.g. [13-15]), much interpretation of the global and local MORB trends has been based on the results of laboratory experiments that melted uniform peridotite sources under anhydrous conditions (e.g. [16-18]). The presence of water lowers the mantle mineral solidus temperatures and promotes greater degrees of melting (e.g. [19-21]). Higher water contents increase $\mathrm{Si} 8$ and $\mathrm{Ca} 8$, decrease $\mathrm{Fe} 8$ and $\mathrm{Na} 8$, when compared to anhydrous melts on a volatile-free basis [20]. Furthermore, the presence of water delays the onset, and changes the composition, of plagioclase fractionation [22-25]. Suppressing plagioclase crystallization relative to olivine produces higher Al8 and lower Fe8. The net result is that, compared to MORB, BAB lavas show greater compositional variations and exaggerated major element trends, providing a fruitful environment in which to study crustal accretion processes.

In this paper we first discuss the geochemical data, and our corrections for crystal fractionation, for lavas from the Lau, Manus, Mariana and east Scotia BABs (Fig. 1). We then crossplot key chemical indices and discuss what their trends reveal about the addition of water from the subducting slab and its effects on extents of mantle melting. Finally, we evaluate a physical model of mantle corner flow and melting [26,27] in light of the observed geochemical trends.

\section{Data and fractionation corrections}

Comprehensive geochemical analyses of closely spaced axial samples have been published for the Lau [28-36], Manus [37], Mariana [38-42] and east Scotia $[43,44]$ basins. Our data base, compiled from these publications, primarily uses analyses of fresh glasses and is available ${ }^{1}$. Additional unpublished analyses were provided by P. Fryer, J. Pearce and R. Stern for Mariana Trough samples south of $15^{\circ} \mathrm{N}$ and by E. Stolper and S. Newman for water analyses of segment E2 samples from the east Scotia Basin. We consulted original swath bathymetry and/or sidescan surveys of the spreading axes to limit analyses to samples from the neovolcanic zones and to exclude fractionated samples from propagation tips. Overviews of the tectonic setting and evolution of each of the BABs (Fig. 1) are provided in the following papers: Lau [45], Manus [46], Mariana [47], and east Scotia [48]; as well as in [27].

Laboratory experiments [16-22] indicate that higher pressure melts have higher $\mathrm{FeO}$ and that melting to greater extents lowers the contents of incompatible elements such as $\mathrm{Na}_{2} \mathrm{O}$. The global MORB trend of decreasing $\mathrm{Na} 8$ with increasing $\mathrm{Fe} 8$ is therefore correlated with increasing mantle potential temperatures [1-3]. To investigate such systematics in the $\mathrm{BAB}$ basalt $(\mathrm{BABB})$ data we corrected the published geochemical analyses for the effects of varying crystal fractionation by calculating compositions at a common $8 \% \mathrm{MgO}$. To limit possible errors introduced by this correction, in most cases we used only analyses with $6-8.5 \%$

\footnotetext{
${ }^{1}$ See tables 1-4 in the online version of this article.
} 

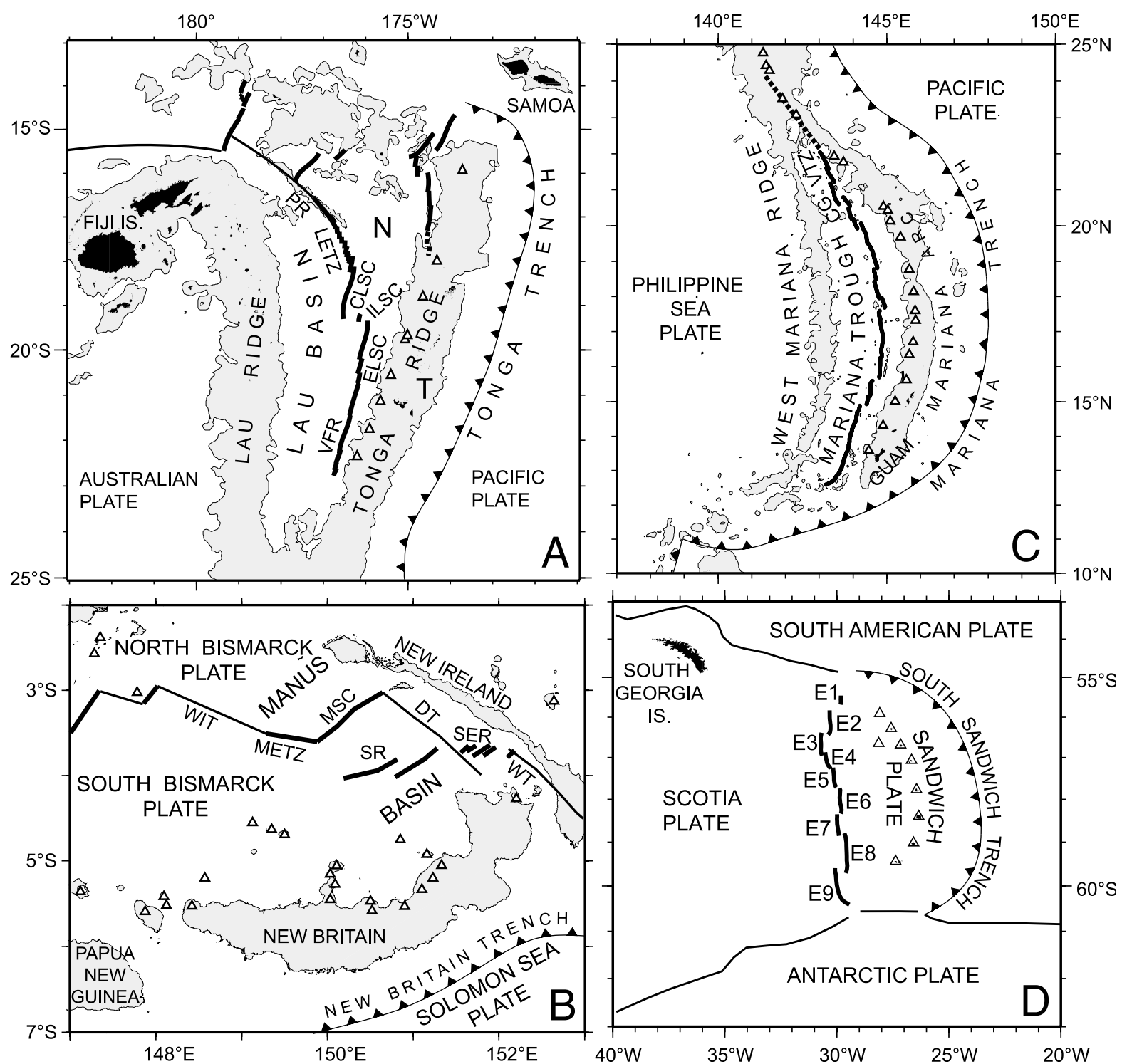

Fig. 1. Back-arc basin location diagrams. Thick lines are spreading segments, dashed lines are rifts, thin lines are transform faults, triangles locate volcanoes. Spreading segment abbreviations include: (A) CLSC, Central Lau Spreading Center; ILSC, Intermediate Lau Spreading Center; ELSC, East Lau Spreading Center; VFR, Valu Fa Ridge; (B) METZ, Manus Extensional Transform Zone; MSC, Manus Spreading Center; SR, Southern Rifts; SER, SE Ridges; (C) CG, Central Graben; VTZ, Volcano Tectonic Zone. Transform abbreviations include: (A) PR, Peggy Ridge; (B) DT, Djaul Transform; WT, Weitin Transform; WIT, Willaumez Transform.

$\mathrm{MgO}$. In some instances, especially for shallow ridges dominated by fractionated lavas, we included samples with as little as $5 \% \mathrm{MgO}$.

To account for varying liquid-lines-of-descent and the varying compositions of fractionating minerals, as a function of melt composition, Plank and Langmuir [49] calculated:

$\mathrm{Na} 8=\left[\mathrm{Na}_{2} \mathrm{O}+0.115(8-\mathrm{MgO})\right] /[1+0.133(8-\mathrm{MgO}]$.

We, like Leat et al. [43], used this equation for 
all samples, which facilitates comparisons of our results between basins and with MORB.

From an inspection of the BABB data, we derived the similar equation:

$\mathrm{Fe} 8=[\mathrm{FeO} *+8-\mathrm{MgO}] /[1+0.25(8-\mathrm{MgO})]$

where $\mathrm{FeO}^{*}$ expresses all iron as $\mathrm{Fe}^{2+}$. This function lowers the fractionation slopes as Fe8 decreases, in accordance with predicted trends and other data $[15,20,24,25]$. It does not account for the reversal in slope at the onset of plagioclase crystallization, which occurs at lower $\mathrm{MgO}$ values for higher water contents [20-25]. However, the reduced slopes limit the size of this error in Fe8 typically to \pm a few tenths of $1 \%$ (too high for $\mathrm{MgO}>8 \%$, too low for $\mathrm{MgO}<8 \%$ ). Such errors are small compared to the range of $\mathrm{FeO}(\sim 4 \%$ at $7-7.5 \% \mathrm{MgO}$ ) observed in each basin.

Fractionation of incompatibles such as $\mathrm{TiO}_{2}$ and $\mathrm{H}_{2} \mathrm{O}$ is better described by power-law equations. We used the following equations, which also change slope with composition:

$\mathrm{Ti} 8=\left(\mathrm{TiO}_{2}\right)(\mathrm{MgO})^{1.7} / 34.3$

$\mathrm{H}_{2} \mathrm{O}(8)=\left(\mathrm{H}_{2} \mathrm{O}\right)(\mathrm{MgO})^{1.7} / 34.3$ where $34.3=8^{1.7}$

$\mathrm{TiO}_{2}$ is moderately incompatible and therefore a useful independent index of the degree of partial melting. Its concentration, and that of similarly incompatible elements $\mathrm{Y}$ and $\mathrm{Yb}$, systematically decreases as the total extent of melting increases. Although we calculated Y8 and Yb8, we do not show them here because they linearly co-vary with Ti8. Their covariance is an important observation because it means that $\mathrm{TiO}_{2}$ (at $\mathrm{MgO}>5-6 \%$ ) is not affected by titanomagnetite fractionation (despite higher water contents producing higher saturation temperatures of oxides with respect to silicates [25]).

We show $\mathrm{H}_{2} \mathrm{O}$ data (measured by Fourier transform infrared spectroscopy) and $\mathrm{Ba} / \mathrm{La}$ ratios, where available, as indications of mantle source enrichments by components progressively released from the subducting slab. Other indices (such as $\mathrm{Ba} / \mathrm{Nb}$ and $\mathrm{Th} / \mathrm{Zr}$ ), available in the referenced publications, provide complementary indications of subduction influence.

\section{Compositional systematics}

\subsection{Lau Basin}

Along the spreading axes of the Lau Basin, there is a first-order progression from arc-like to MORB-like lava compositions with increasing distance away from the Tofua arc (e.g. [34]). Samples from the arc-proximal and shallow Valu $\mathrm{Fa}$ Ridge (VFR) and southern East Lau Spreading Center (sELSC) have the lowest $\mathrm{Na} 8$ and Ti8, and the highest $\mathrm{Ba} / \mathrm{La}$ and $\mathrm{H}_{2} \mathrm{O}(8)$ (Figs. 2 and 3). In contrast, samples from the Central Lau Spreading Center (CLSC), furthest from the arc, have the highest $\mathrm{Na} 8$ and Ti8, and the lowest $\mathrm{Ba} /$ La and $\mathrm{H}_{2} \mathrm{O}(8)$. Plotted against Fe8 (Fig. 3), Na8 and Ti8 show positive correlations, with VFR (and some sELSC) and CLSC lavas forming the low- and high-value end-members, respectively. These relationships are independent of spreading rate, which increases northward along the VFR and ELSC from 40 to $95 \mathrm{~mm} / \mathrm{yr}$, and then decreases northward along the CLSC from 92 to $85 \mathrm{~mm} / \mathrm{yr}$ [45]; nor do they correlate simply with axial depth (Fig. 2).

Within this first-order trend from arc- to MORB-like compositions, there are numerous

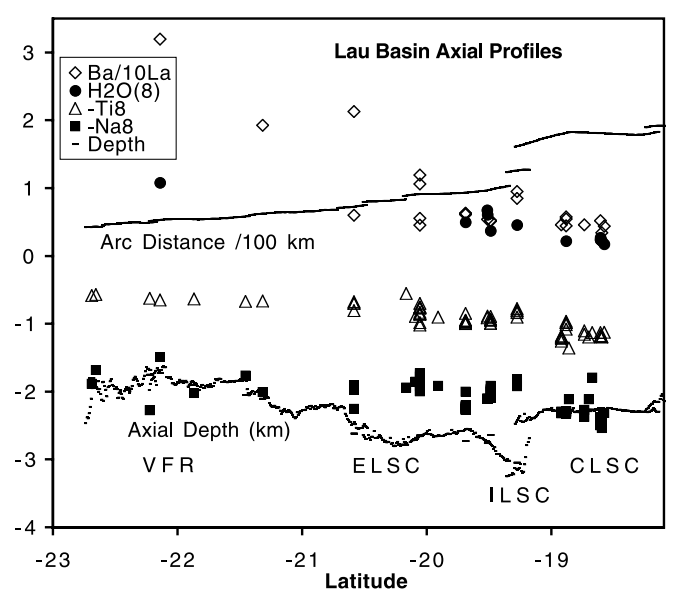

Fig. 2. Latitudinal profile of geochemical values, depth, and distance from the Tofua island arc along the axes of the Lau Basin spreading centers south of $18^{\circ} \mathrm{S}$. Spreading rates increase northward along the VFR and ELSC from 40 to 95 $\mathrm{mm} / \mathrm{yr}$, and then decrease northward along the CLSC from 92 to $85 \mathrm{~mm} / \mathrm{yr}$ [45]. 


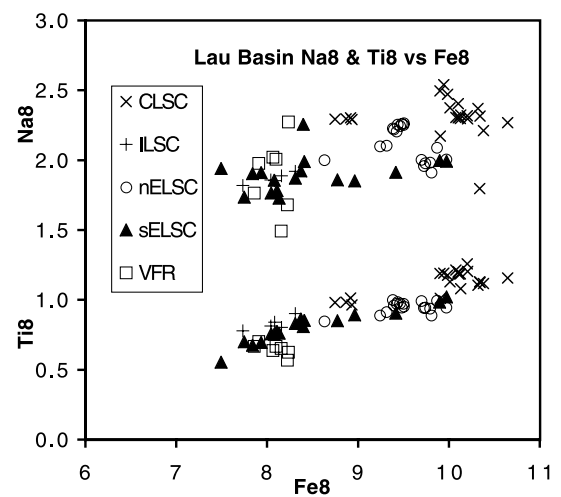

Fig. 3. Plot of Ti8 and $\mathrm{Na} 8$ versus $\mathrm{Fe} 8$ for Lau Basin spreading axis lavas south of $18^{\circ} \mathrm{S}$. Abbreviations as in Fig. 1 except for ELSC, where $\mathrm{n}=$ north of $20^{\circ} \mathrm{S}$ and $\mathrm{s}=$ south of $20^{\circ} \mathrm{S}$.

subtleties and variations from a simple progression. For example, samples from the same location (e.g. at $\sim 18.9^{\circ} \mathrm{S}, 20.06^{\circ} \mathrm{S}, 20.6^{\circ} \mathrm{S}$ and $22.2^{\circ} \mathrm{S}$, Fig. 2) and spreading segment (Fig. 3) often show significant compositional variability. Similarly, samples farther from the arc (like those of the Intermediate Lau Spreading Center, ILSC) may be more arc-like than samples closer to the arc

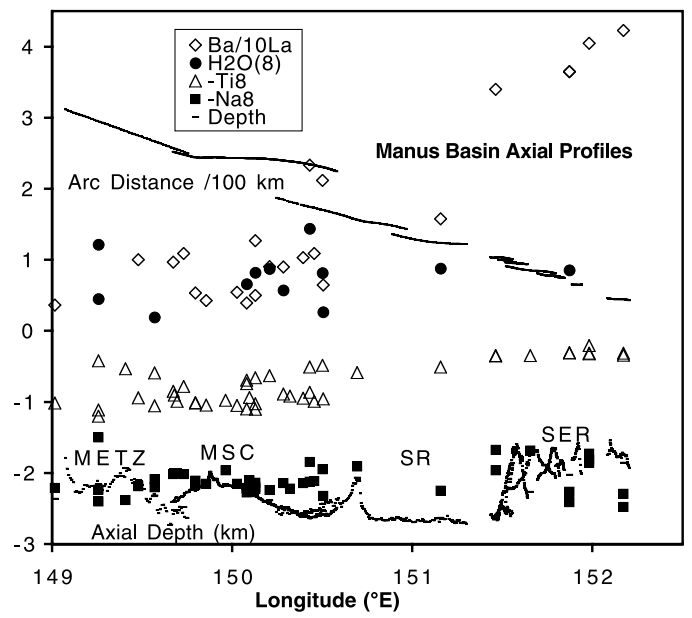

Fig. 4. Longitudinal profile of geochemical values, depth, and distance from the New Britain arc volcanic front along the axes of the Manus Basin spreading centers: MSC, Manus Spreading Center; SR, southern Rifts; SER, Southeast Ridges; METZ, Manus Extensional Transform Zone. GPSderived spreading rates (not shown) increase from $\sim 115$ $\mathrm{mm} / \mathrm{yr}$ at the METZ/MSC overlap to $145 \mathrm{~mm} / \mathrm{yr}$ at the easternmost SER [50]. (like those of the northern East Lau Spreading Center, nELSC, Fig. 3).

\subsection{Manus Basin}

The spreading axes of the Manus Basin also show a systematic variation from arc-like to MORB-like lava compositions with increasing distance away from the New Britain arc [37], though in this case GPS measurements indicate that the segments closest to the arc are spreading the fastest, $135-145 \mathrm{~mm} / \mathrm{yr}$ [50]. Samples from the arc-proximal and shallow Southeast Ridges (SER), have the highest $\mathrm{Ba} / \mathrm{La}$ and lowest Ti8 (Fig. 4). Their $\mathrm{Na} 8$ is variable, ranging from some of the lowest to the highest values (Fig. 5), reflecting at least two different end-member arclike source types. Their high vesicularity reflects high water contents, although the sole value measured on a moderately fractionated sample is only $0.86 \% \mathrm{H}_{2} \mathrm{O}(8)$, probably because the lava partially degassed when erupted at $2 \mathrm{~km}$ water depth.

In contrast, MORB-like samples (types M1 and M2 of [37]) from the Manus Spreading Center and Extensional Transform Zone (MSC and METZ), furthest from the arc, have the highest Ti8 and Fe8 (Fig. 5), and the lowest $\mathrm{Ba} / \mathrm{La}$ and $\mathrm{H}_{2} \mathrm{O}(8)$ (Fig. 4). Plotted against Fe8 (Fig. 5), Ti8 shows positive correlations, with SER and MSC lavas forming the low- and high-value end-mem-

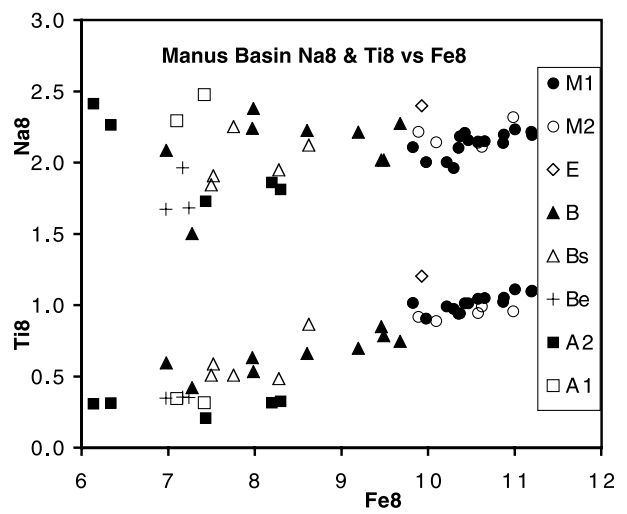

Fig. 5. Plot of $\mathrm{Ti} 8$ and $\mathrm{Na} 8$ versus $\mathrm{Fe} 8$ for Manus Basin spreading axis lavas. Geochemical groups [37], labeled M1A1, have the following distribution: A1+A2, SER; Be, western SER; Bs, SR; M2, northeast MSC, M1 and B, MSC and METZ, E, METZ. 
bers, respectively. $\mathrm{Na} 8$, on the other hand, forms a triangular distribution when plotted against Fe8 (Fig. 5). Unlike the other BABs, there is evidence that sodium is added with other subduction components to the Manus mantle source [37].

There are three groups of BABBs erupted in the Manus Basin and they systematically vary in location and composition between the Manus MORB- and arc-like end-members [37]. Group Be is from the axial deep that is the western segment of the SER, group Bs is from the Southern Rifts (SR), and group B lavas occur from the central MSC to the METZ (Fig. 4). Fe8 and Ti8 contents sequentially increase (Fig. 5) and $\mathrm{Ba} / \mathrm{La}$ contents progressively decrease (Fig. 4) in the order $\mathrm{Be}, \mathrm{Bs}, \mathrm{B}$, corresponding to increasing distance to, and decreasing source contributions from, the arc/slab.

BABB (group B) and MORB-like (group M1) lavas erupt together on the central and western MSC and on the METZ. Group B lavas are characterized by higher $\mathrm{Ba} / \mathrm{La}$ and $\mathrm{H}_{2} \mathrm{O}(8)$ (Fig. 4), and lower Ti8 and Fe8, than group M1 lavas (Fig. 5). Both lava types were recovered in the same dredge haul at $149.3^{\circ} \mathrm{E}$ and $150.1^{\circ} \mathrm{E}$ (Fig. 4 ; [37]), indicating significant local source heterogeneity.

Overall, the Manus Basin lavas reveal progressively greater extents of melting of progressively more depleted mantle that has been progressively enriched in slab-derived components in the sequence M1-M2-B-Bs-Be-A2-A1, which (except for $\mathrm{B})$ corresponds to decreasing distance to the New Britain island arc [37].

\subsection{Mariana Trough}

GPS-derived spreading rates increase from 26 $\mathrm{mm} / \mathrm{yr}$ towards $070^{\circ}$ at $18^{\circ} \mathrm{N}$ to $45 \mathrm{~mm} / \mathrm{yr}$ towards $097^{\circ}$ at $13.5^{\circ} \mathrm{N}$, consistent with a pole of Mariana Trough opening near (but southeast of) the northern apex of the basin [51]. The first-order segment-scale depth and geochemical differences are between lavas from the arc-proximal regions $\left(<13.5^{\circ} \mathrm{N}\right.$, and $>21^{\circ} \mathrm{N}$ : the volcano-tectonic zone, VTZ, including rifting north of $\sim 22^{\circ} \mathrm{N}$ ) and those from the spreading axes in between (Figs. 1 and 6). The VTZ lavas are transitional

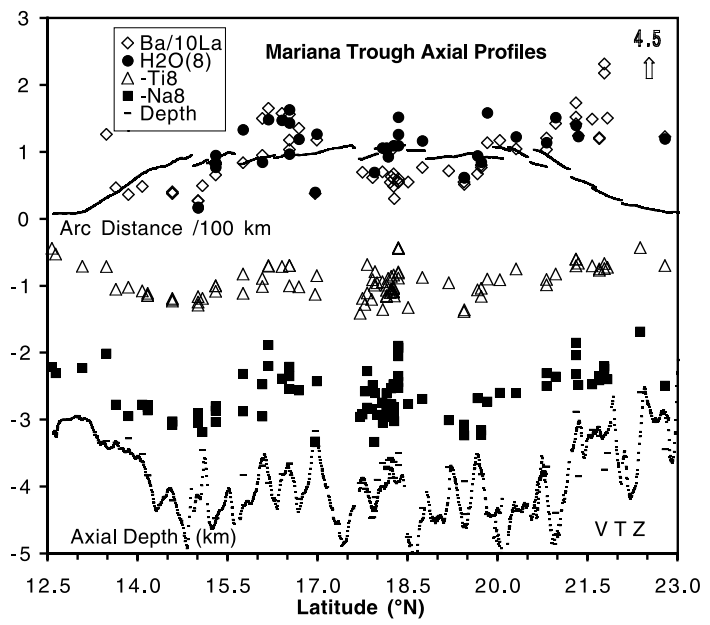

Fig. 6. Latitudinal profile of geochemical values, depth, and distance from the Mariana island arc along the spreading axis of the Mariana Trough. One $\mathrm{Ba} / \mathrm{La}$ value (45, arrowed) is off the scale of this plot. Axial depths exceed $5 \mathrm{~km}$ just north of $20^{\circ} \mathrm{N}$. GPS-derived spreading rates (not shown) increase from $26 \mathrm{~mm} / \mathrm{yr}$ towards $070^{\circ}$ at $18^{\circ} \mathrm{N}$ to $45 \mathrm{~mm} / \mathrm{yr}$ towards $097^{\circ}$ at $13.5^{\circ} \mathrm{N}$ [51].

in major, trace and isotope compositions between the Mariana Trough Basalts (MTB) and nearby island arc lavas [39,42], with characteristically high $\mathrm{Ba} / \mathrm{La}$ and $\mathrm{H}_{2} \mathrm{O}(8)$ and low $\mathrm{Na} 8$, Ti8 and Fe8 (Fig. 6). Unpublished analyses (P. Fryer, J. Pearce and R. Stern, personal communications, 2003) indicate that the lavas also become arclike south of $13.5^{\circ} \mathrm{N}$, where the spreading center transitions from a rifted valley to an axial high (Fig. 6). Like many of the most arc-like VTZ samples, an andesite $\left(55.95 \% \quad \mathrm{SiO}_{2}\right)$ dredged from the ridge axis at $13^{\circ} 20^{\prime} \mathrm{N}$ is not plotted in our figures because it is so fractionated $(\mathrm{Mg} \ll 5 \%)$ that it fails our sample selection criteria.

The MTB from the spreading axes at $13.5^{\circ}-$ $21^{\circ} \mathrm{N}$ range between normal MORB-like (e.g. $15^{\circ} \mathrm{N}$ ) and arc-like (e.g. $18.35^{\circ} \mathrm{N}$ ) compositions (Fig. 7) [38,41,42,52,53]. Na8 and Ti8 correlate positively with $\mathrm{Fe} 8$ along one principal trend, with a few (mainly arc-like) samples offset to lower Na8 and Ti8 values (Fig. 7). From the only two DSDP holes to penetrate MTB (Sites 454 and 456), Wood et al. [54] reported a BABB series with end-member MORB-like and arc-like compositions inter-layered. The full range of compo- 
sitions (MORB-like, BABB and arc tholeiite) is also present in close proximity on axis (e.g. at $16^{\circ} \mathrm{N}$, and at $17.8-18.35^{\circ} \mathrm{N}$, Figs. 6 and 7), confirming major source heterogeneity. Stolper and Newman [40] showed that melting mixtures of a MORB-type mantle source with, and in direct proportion to the amount of, a $\mathrm{H}_{2} \mathrm{O}$-rich component can produce the range of MTB observed.

\subsection{East Scotia Basin}

Like the Mariana Trough, the east Scotia Basin spreading axis has arc-proximal shoal segments (E2 and E9) on both ends but is characterized by axial graben for most of its length (Fig. 8) [48]. The morphological variation cannot be ascribed to spreading rates, which vary little along strike $(60-70 \mathrm{~mm} / \mathrm{yr})$. There is a seismically imaged melt lens under segment E2 and a caldera at the summit of segment E9 [55,56]. The enhanced melting to form the E2 and E9 ridges has been attributed to the flow of enriched mantle around the ends of the subducted slab, bringing with it both an Atlantic hotspot and a South Sandwich arc signature $[55,56]$.

The geochemistry of the axial lavas broadly supports these inferences. There is both a plume (e.g. high $\mathrm{La} / \mathrm{Yb}$ ) and a subduction (e.g. high $\mathrm{Ba} /$ $\mathrm{La}$ and $\mathrm{H}_{2} \mathrm{O}(8)$ ) component in the E2 and E9 lavas (Fig. 8) [43,44]. In addition, however, there is a subduction component (with high $\mathrm{H}_{2} \mathrm{O}$ and

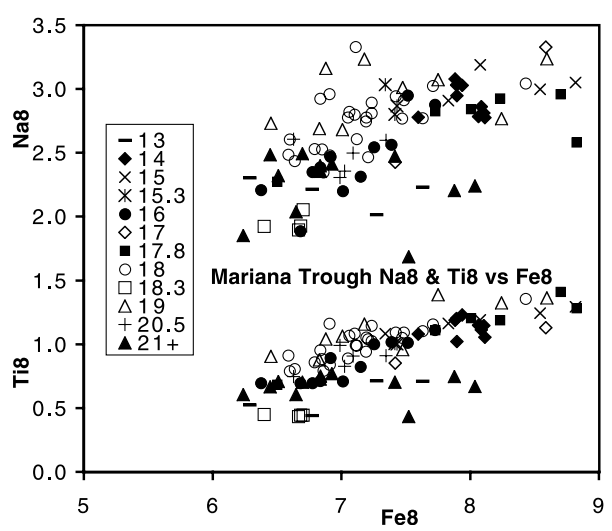

Fig. 7. Plot of Ti8 and Na8 versus Fe8 for Mariana Trough spreading axis lavas. The numbers in each group label (13$21+$ ) indicate latitude.

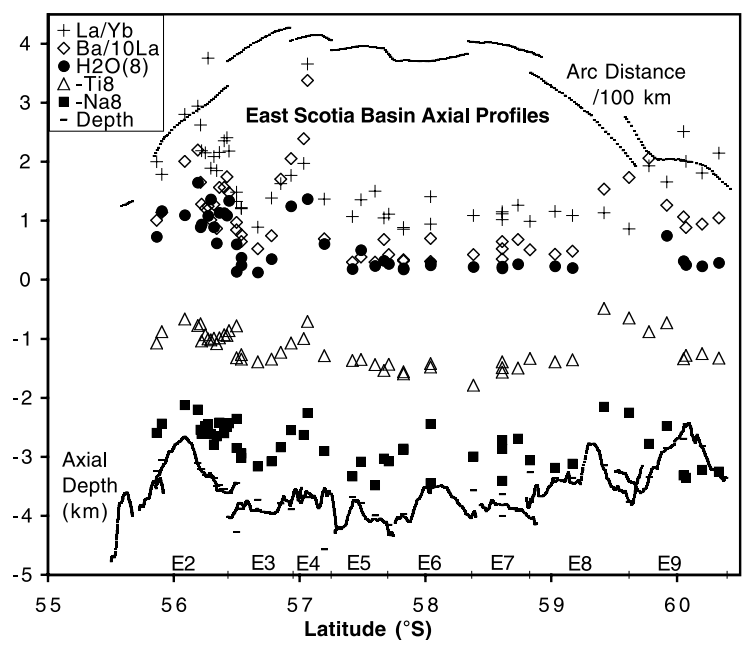

Fig. 8. Latitudinal profile of geochemical values, depth, and distance from the South Sandwich island arc along the spreading axis of the east Scotia Basin (segments E2-E9 $[43,44]) . \mathrm{La} / \mathrm{Yb}$ data are plotted as one indicator of possible plume influence. Spreading rates calculated from magnetic anomalies are $60-70 \mathrm{~mm} / \mathrm{yr}$ [48].

$\mathrm{Ba} / \mathrm{La}$ ), ascribed to a sediment melt, in E3/E4 and a depleted arc-like component in the southern E8 and northern E9 lavas [44] although none of these are associated with shallow depth anomalies. The central spreading segments, E5-E7, as well as the center of E3 and the north of E8, have MORBlike compositions (Figs. 8 and 9). The MORB-like compositions $(\sim \mathrm{Fe} 8>7.5)$ show decreasing $\mathrm{Na} 8$ with increasing $\mathrm{Fe} 8$ (Fig. 9) that matches the

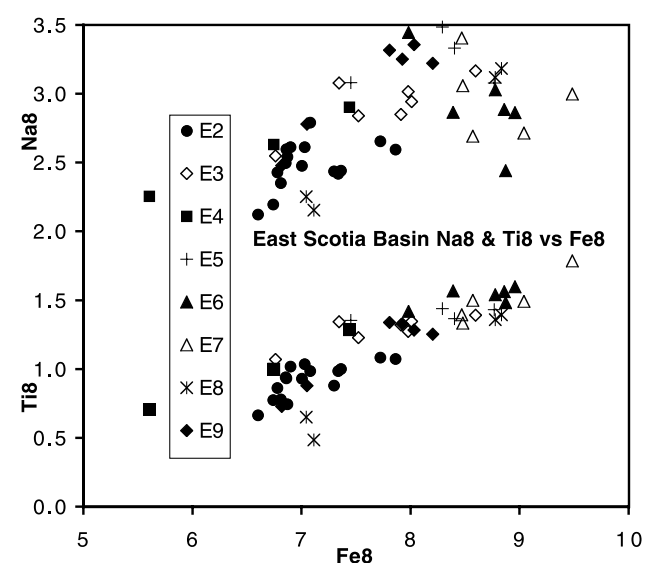

Fig. 9. Plot of Ti8 and Na8 versus Fe8 for east Scotia Basin spreading axis lavas (segments E2-E9). 
global MORB trend (Fig. 10) and reflects a positive correlation between the average degree and pressure of melting of the least hydrous samples. The larger variation in $\mathrm{Na} 8$ and $\mathrm{Ti} 8$ versus $\mathrm{Fe} 8$, however, is towards decreasing $\mathrm{Na} 8$ and $\mathrm{Ti} 8$ with decreasing Fe8. This is caused by a MORB-like source (the low-degree-melt end-member) mixing with, and melting in proportion to, the amount of a depleted arc-like source with high water contents. The axial lava compositions of segment E3 are particularly heterogeneous, with compositions within this one segment ranging from the MORB- to arc-like end-members (Fig. 9).

\section{Inter-basin comparison}

To further compare the similarities and differences in the compositional trends represented by lavas from the Lau, Manus, Mariana and east Scotia basins, we plot $\mathrm{Na} 8$, Ti8, and $\mathrm{H}_{2} \mathrm{O}(8)$, all versus $\mathrm{Fe} 8$, and $\mathrm{Ba} / \mathrm{La}$ versus Ti8, from the four BABs in Figs. 10-13, respectively. The MORBlike end-members of the four basins fall along

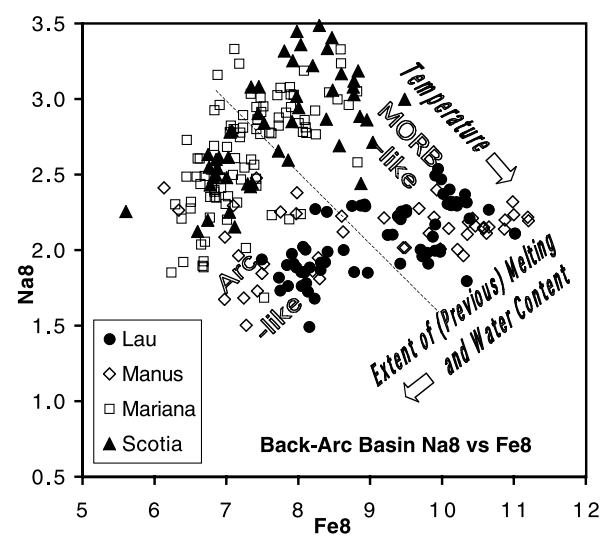

Fig. 10. Plot of $\mathrm{Na} 8$ versus $\mathrm{Fe} 8$ for $\mathrm{BAB}$ lavas. The least melted (highest Ti8, Fig. 11) and least hydrous (Fig. 12) samples fall along the global MORB array of $\mathrm{Na} 8$ versus Fe8 compositions (most of which plot above the dashed line), reflecting a positive correlation between the average degree and pressure of decompression melting, both of which increase with mantle temperature [1-3]. BABB compositions decrease in $\mathrm{Fe} 8$ and $\mathrm{Na} 8$ as the water content and total extent of melting (including prior melting) increase toward the arc-like (subduction component) end-members within each basin.

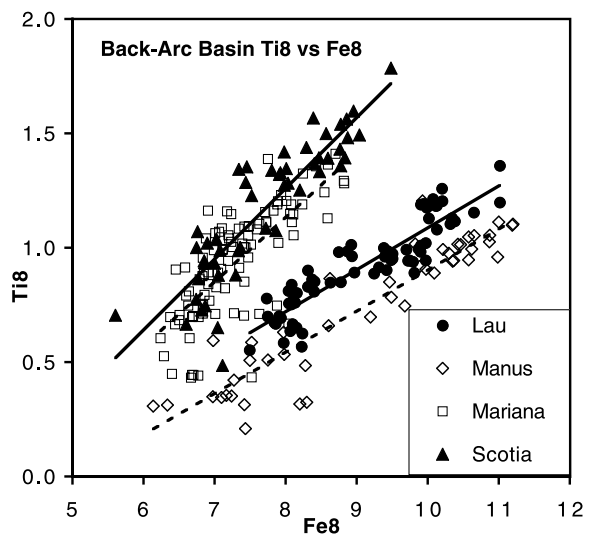

Fig. 11. Plot of Ti8 versus Fe8 for BAB lavas. Lines show linear best fits to the data for each basin. Total extent of melting increases as Ti8 decreases.

the global MORB array of decreasing $\mathrm{Na} 8$ with increasing Fe8 (Fig. 10), reflecting a positive correlation between the average degree and pressure of decompression melting as a result of regional variations in mantle potential temperature [1-3]. These end-members have the highest Ti8 and so represent the least melted mantle sources within each basin (Fig. 11). They also have the lowest $\mathrm{H}_{2} \mathrm{O}(8)$ and $\mathrm{Ba} /$ La (Figs. 12 and 13).

The Ti8 versus $\mathrm{Fe} 8$ trends are offset between the four basins in the order east Scotia, Mariana, Lau and Manus, from highest to lowest Ti8 (Fig. 11). Na8 versus $\mathrm{Fe} 8$ trends overlap for Scotia and Mariana and are each higher in $\mathrm{Na} 8$ than the overlapping trends for Lau and Manus (Fig.

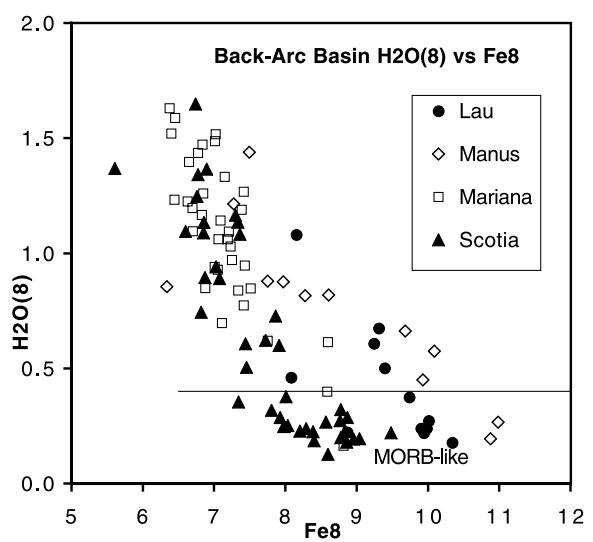

Fig. 12. Plot of $\mathrm{H}_{2} \mathrm{O}(8)$ versus $\mathrm{Fe} 8$ for $\mathrm{BAB}$ lavas. For comparison, most MORBs plot below the line [13,15]. 
10). These trends fit the first-order global MORB trend of compositions versus average ridge depths [2], the spreading segments of the Manus (1500$2700 \mathrm{~m})$ and Lau (1500-3200 m) being shallower than those of the Mariana $(2500-5500 \mathrm{~m})$ and east Scotia (2400-4100 m) basins.

Much of the inter-basin geochemistry and depth variation can be explained by variable pressures and extents of mantle partial melting that match global MOR trends associated with mantle potential temperature variations (i.e. Lau and Manus source regions are hotter than Mariana and Scotia). The Na8-Fe8 BAB variations are about two-thirds of the global MOR ones, implying temperature differences of about $200^{\circ} \mathrm{C}$ if all the global variations are ascribed to temperature differences of a compositionally homogeneous mantle [1,2]. Given that subduction rates are fast beneath Lau and Manus ( $>140 \mathrm{~mm} / \mathrm{yr}$ [57,58] but slow to intermediate beneath Mariana and Scotia (40-70 and $67-79 \mathrm{~mm} / \mathrm{yr}[48,51])$, this is consistent with the correlation between subduction rate and mantle wedge temperature predicted by numerical models $[59,60]$. In these models fast subduction induces fast mantle wedge advection and isotherms compressed against the slab, whereas slow subduction and advection allow significant cooling of the mantle wedge.

The arc-like end-members of the BAB compositional spectrum show evidence of hydrous flux melting, being enriched in water and other incom-

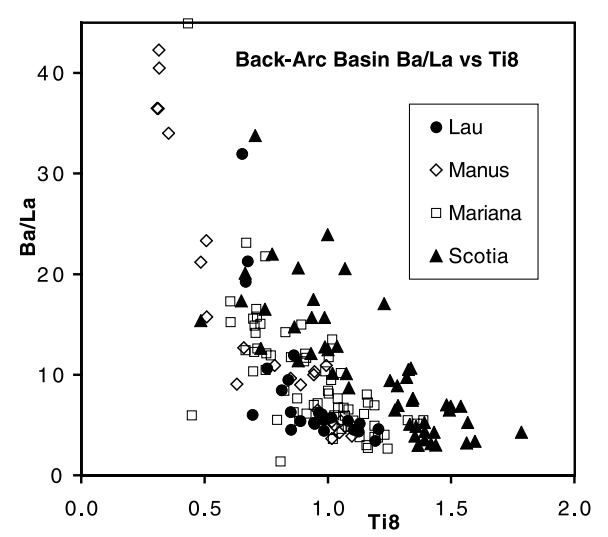

Fig. 13. Plot of $\mathrm{Ba} / \mathrm{La}$ versus $\mathrm{Ti} 8$ for $\mathrm{BAB}$ lavas. Greater slab contributions (higher $\mathrm{Ba} / \mathrm{La}$ ) correlate with greater extents of melting (lower Ti8).

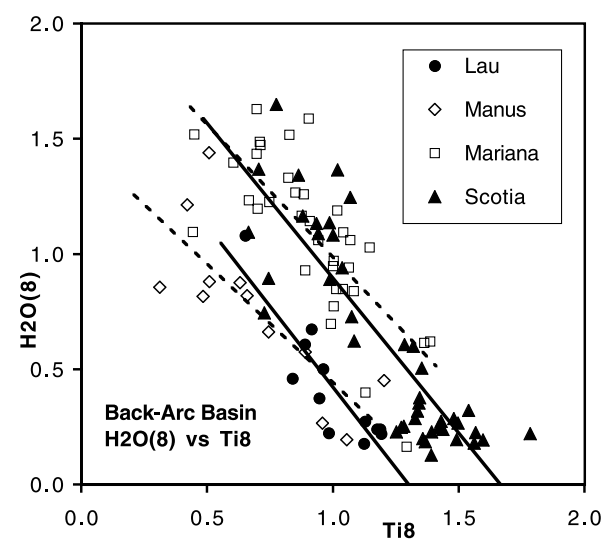

Fig. 14. Plot of $\mathrm{H}_{2} \mathrm{O}(8)$ versus $\mathrm{Ti} 8$ for $\mathrm{BAB}$ lavas. Lines show linear best fits to the data for each basin. Higher water contents correlate with greater extents of melting (lower Ti8).

patible elements (e.g. Ba/La) derived from subduction (Figs. 12 and 13). They are characterized by low Na8, Ti8, (and Fe8, Figs. 10 and 11), indicating high extents of total melting. As shown in Figs. 10-13, they have a range of compositions, both within individual basins (especially Manus and Mariana) and between the four basins. This range reflects, amongst other things, differing amounts of alkalis and large ion lithophile elements (LILE) added by subduction components. Note that, although arc-like, these end-members are not identical to adjacent frontal arc lavas, which themselves have a range of compositions that typically sub-parallel the $\mathrm{Na} 8$ and Ti8 versus $\mathrm{Fe} 8$ trends of their back-arc lavas, but often at even lower Na8 and Ti8 (e.g. [42,60-62]). Rather, they reflect components derived from the progressive release of fluids from the subducted slab (and their sequential reactions with the overlying mantle), including components sourced and/or equilibrated deeper than those influencing the volcanic front.

Compositionally between the MORB- and arclike end-members are suites of BABB (Figs. 10 and 11) formed by melting of variable mixtures of the end-member sources. As shown by Stolper and Newman [40] and Sinton et al. [37] for the Mariana and Manus basins, respectively, a plot of $\mathrm{H}_{2} \mathrm{O}(8)$ versus Ti8 confirms that the total extent of melting is proportional to the amount of water present (i.e. decreasing Ti8 correlates with increas- 


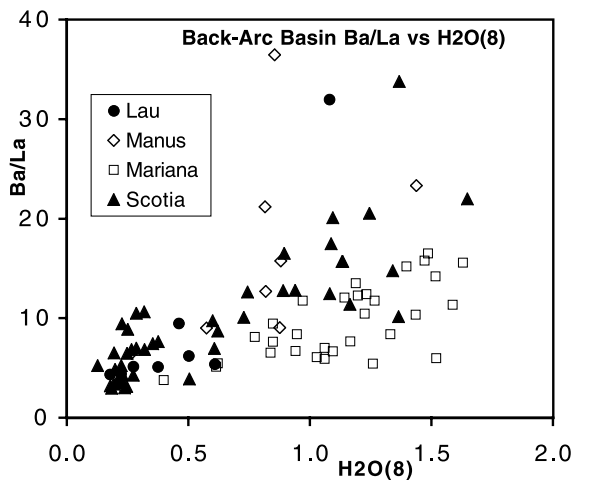

Fig. 15. Plot of $\mathrm{Ba} / \mathrm{La}$ versus $\mathrm{H}_{2} \mathrm{O}(8)$ for $\mathrm{BAB}$ lavas. Greater slab contributions (higher $\mathrm{Ba} / \mathrm{La}$ ) correlate with higher water contents. The $\mathrm{Ba} / \mathrm{La}$ to water ratio is lowest for the Mariana Trough and highest for the Lau and Manus basins (also compare Figs. 13 and 14).

ing $\mathrm{H}_{2} \mathrm{O}(8)$, Fig. 14). $\mathrm{Ba} / \mathrm{La}$ ratios are also highest in the lowest Ti8 and highest $\mathrm{H}_{2} \mathrm{O}(8)$ lavas (Figs. 13-15), indicating that the greatest contributions of other slab components are also to the most hydrous and melted sources.

These systematics for the BAB samples are representative of the more general relationship that the total extent of melting (as measured by high field strength element [HFSE] and heavy rare earth element [HREE] depletions relative to MORB) is tied to sympathetic slab-fluid enrichments (as measured by LILE and $\mathrm{H}_{2} \mathrm{O}$ contents) [34-44,63]. This is in marked contrast to the decrease in mean extent of melting observed in MORBs, where regional enrichments in source water content produce a long low-extent-of-melting tail at the base of the melting column [64]. The supply of fluids to the supra-subduction zone (SSZ) mantle wedge is able to sustain back-arc melting of even previously (melt) depleted sources.

\subsection{Extents of mantle melting}

For the Mariana Trough, estimates of the total degree of melting from $\mathrm{Ti}-\mathrm{Yb}$ systematics range from 7 to $16 \%$ for $\mathrm{MTB}$, and from 12 to $36 \%$ for VTZ and $18.35^{\circ} \mathrm{N}$ lavas [42]. Likewise, assuming that MORB-type M1 magmas in the Manus Basin were generated by $10 \%$ total fusion, Sinton et al. [37] showed from $\mathrm{Nb}, \mathrm{Zr}$ and $\mathrm{Ti}$ versus $\mathrm{Y}$ data that the sequence B, Bs, Be and A2 (Fig. 5) would require successively greater extents of melting of the same source, from $16 \%$ up to a maximum of over $40 \%$. Such high extents of melting (beyond the exhaustion of major mantle phases such as clinopyroxene at $20-25 \%$ ) are unlikely in single melting systems (e.g. $[1,65]$ ).

The alternative is that the BAB lavas were derived from melts of sources already variably depleted in Ti, Y, Yb and other HFSE and HREE relative to the source for MORB. This is the commonly accepted interpretation for island arc lavas, whose HFSE and HREE depletions are so great that they are inferred to result from the melting of sources residual to previous melting (e.g. $[60,65,66])$. The prior melting is often attributed to current or former back-arc spreading (e.g. $[60,61,67,68])$. However, one of the highest levels of arc depletion is sustained in the Izu-Bonin arc for $>12 \mathrm{Myr}$ without back-arc spreading [69]. From this we infer that regular arc processes such as ongoing hydrous fluxing of the arc sources [40] and magmatism behind the volcanic front $[66,69,70]$ are capable of sustaining the heterogeneity of the mantle wedge (i.e. depletion of arc sources relative to behind-the-arc and MORB sources).

The extent of mantle melting reflects the combination of four effects: the depression of the mantle solidus as a function of water content (hydrous flux melting), the amount of adiabatic upwelling above the solidus (decompression melting), the original composition of the mantle (which may have experienced prior melting), and mantle temperature. Thus measures of extents of melting do not translate directly into crustal production in arc-backarc settings, but rather reflect the total history of melt extraction. Crustal production will depend on the fraction of current (not former) hydrous and decompression melting, multiplied by the (arc or back-arc) volume of mantle melting, minus the amount of melt retained in the mantle. In BABs, therefore, crustal production provides a different measure than lava geochemistry of the extent of melting. $\mathrm{Na} 8$ and Fe8 do not linearly correlate with depth in each basin, and do so only to first order between basins. 


\section{Discussion}

\subsection{The MT02 model}

To explain the systematic (but non-linear) variations in magma production and composition as a function of distance from the volcanic front, Martinez and Taylor [26,27] proposed a model (MT02) in which back-arc crustal accretion is controlled by the subducting slab, which shapes the thermal, flow and compositional characteristics of the melt source regions in the mantle wedge. They proposed that in BABs an advective system similar to that of MORs (Fig. 16A) is superimposed on a SSZ flow field (Fig. 16B). This allows material that has undergone varying melt extraction and slab input to be re-circulated into the melting regimes of the back-arc spreading centers by mantle wedge corner flow [71] (Fig. 16C-F).

In the MT02 model, SSZ mantle that is progressively depleted of a melt component toward the volcanic front $[66,70]$ is advected toward the wedge corner and downward with the slab (Fig. 16B). When back-arc extension commences it initiates lithospheric plate separation near the rheologically weak volcanic front (Fig. 16C). With increasing extension a seafloor spreading center is established near the volcanic front advecting highly hydrated mantle (Fig. 16D). As a consequence, an enhanced magmatic stage and thick crust result. With continued spreading the extension axis separates from the volcanic front (Fig. 16E). Mantle hydration from the slab decreases. Strongly melt-depleted mantle (created by arc magmatism and/or seafloor spreading) is variably mixed with ambient mantle as a result of corner flow and advection by the spreading center. These conditions result in diminished magmatism and thinner crust. Eventually, the back-arc spreading system separates sufficiently from the volcanic front that it is not significantly affected by hydration, re-circulated melt-depleted mantle, and slabderived geochemical components (Fig. 16F). Spreading centers then advect ambient MORBsource mantle and their crustal accretion characteristics are like MORs, controlled largely by spreading rate.
Below, we evaluate the MT02 model in light of the more detailed geochemical systematics developed herein, including the addition of data from the east Scotia Basin not previously considered by Martinez and Taylor [26,27].

\subsection{Enhanced magmatism}

Consistently in the Lau, Manus, Mariana and east Scotia basins, the extension axis is magmatically robust and shallow when nearest the island arc (segments VFR, SER, $13^{\circ} \mathrm{N} / \mathrm{VTZ}$ and E2/E9 in Figs. 2, 4, 6 and 8, respectively). This relationship is not dependent on spreading rate, which is slow to very slow in the case of the VFR and VTZ, respectively, but it does correlate to first order with lava geochemistry. The arc geochemical signature (as reflected by high $\mathrm{Ba} / \mathrm{La}$ and $\mathrm{H}_{2} \mathrm{O}(8)$, Figs. 12-15) is stronger within each basin along the shallow ridges closest to the island arc (Figs. 2, 4, 6 and 8). Exceptions include segment E4 lavas from the east Scotia Basin and $18.35^{\circ} \mathrm{N}$ arc tholeiites from the Mariana Trough. These arc-like compositions are not associated with robust magmatic segments, probably because they represent local heterogeneities that have not dominated the total crustal production.

In the east Scotia Basin, other source characteristics, specifically Atlantic plume components, also contribute to the shallow ridge segments E2 and E9 $[43,44,48,55,56]$. Thus an additional process that may enhance melting adjacent to the transform-bounded ends of back-arcs, such as east Scotia and northern Lau [72], is flow of enriched mantle around the ends of the subducted slab.

It might be expected from the two-dimensional depiction of the MT02 model in Fig. 16 that lavas erupted during arc rifting and the initiation of back-arc spreading would have arc-like compositions. Although this is known to be the case in the VTZ of the northern Marianas [39], counter-examples include some MORB-like samples from the early opening of the Lau Basin at ODP Site 834 and the BABB lavas from the Sumisu Rift of the Izu-Bonin arc [73-75]. These examples remind us of the horizontally spaced nature of arc volcanism such that rift lavas can be similar to lavas 
from more mature BABs and distinct from contemporaneous volcanic front and cross-chain lavas [76,77]. In the third dimension, not shown in Fig. 16, arc magmatism is spaced along strike and there are regions of little slab influence in between (e.g. [78]). When fast back-arc spreading develops, as in the Lau and Manus basins, the back-arc flow patterns and crustal melt lenses will become more two-dimensional. Slowly opening back-arcs, such as the Mariana Trough, may perpetuate three-dimensional patterns of mantle flow, crustal magmatism and heterogeneiity.
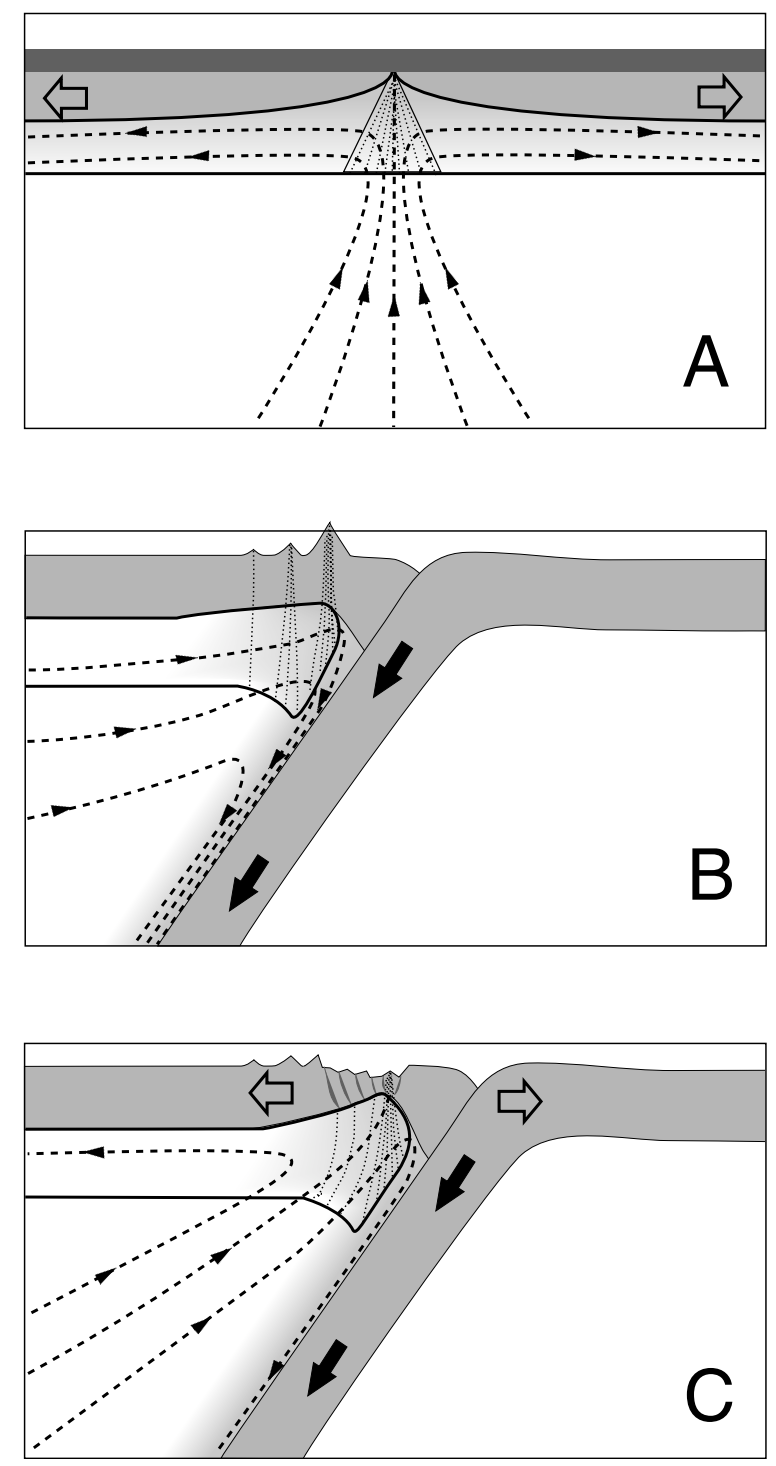

\subsection{Diminished magmatism}

One of the most enigmatic characteristics of BABs are relatively deep segments with lava compositions indicating greater than normal extents of melting. Such is the case for the ELSC of the Lau Basin and the SR of the Manus Basin (Figs. 2 and 4), whose enigmatic characteristics are in marked contrast to those of the more normal CLSC and MSC, respectively, in the same basins but further from their island arcs [26,27,34,37].

The MT02 model explains these apparently
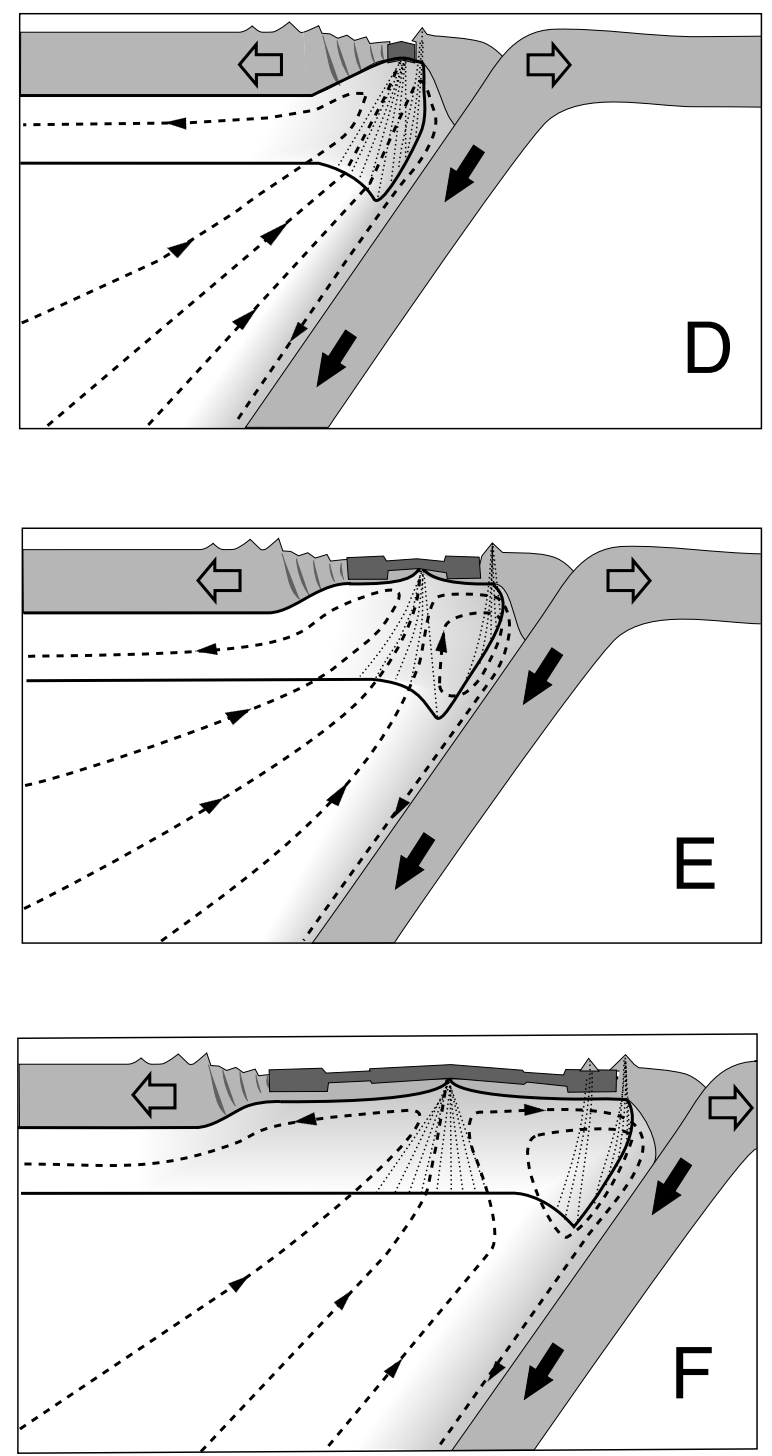
contradictory characteristics by proposing that not all of the melting occurred beneath the present spreading axes. Rather, some component of the mantle source mixture was subject to melt extraction by earlier spreading (analogous to the VFR and SER) and island arc magmatism, that depleted it of incompatible elements (Fig. 16D). Subsequent addition of slab-derived components, including water, during wedge corner flow would allow this depleted source to mix and melt with ambient MORB-source mantle (without extreme depletion characteristics), but not to the extent of the MORB-source end-member (Fig. 16E). The result is a thinner, deeper crust that has a geochemical signature (low Na8, Ti8, Fe8) of high extents of melting. Global MORB compositiondepth systematics do not match this BABB signature.

We note that some samples south of $20^{\circ} \mathrm{S}$ on the ELSC in the Lau Basin do show extreme depletion characteristics (e.g. low Ti8, Fig. 3; as or more depleted than island arc lavas [34]) that likely represent a poorly mixed depleted endmember composition. Similar depletions are evidenced by samples from $59.4^{\circ}$ to $59.9^{\circ} \mathrm{S}$ in the east Scotia Basin (between, not on, the E8 and E9 axial highs, Fig. 8) [44]. The existence of these extreme sample compositions is difficult to explain without corner flow re-circulation of previously melted mantle material.

The possible presence of diminished magmatism between $14^{\circ}$ and $20^{\circ} \mathrm{N}$ in the Mariana Trough is not readily distinguished by its morphology, which is typical of slow-spreading MORs. Nevertheless, it is consistent with the location of the spreading axis (at comparable arc distances to that of the diminished melting parts of the Lau and Manus basins), and the geochemical evidence for mixed mantle sources, often with high water contents [40-42]. Despite near-vertical slab subduction, previously depleted, and subsequently fluid-enriched, mantle sources are circulated at least as far as the central Mariana Trough axis (110 km, Fig. 6).

\subsection{Normal magmatism}

The CLSC and MSC in the Lau and Manus basins, and segments E5-E7 in the east Scotia Basin, at $\sim 180, \sim 240$ and $\sim 380 \mathrm{~km}$, respectively, from their island arcs, are the spreading segments least influenced by slab effects. Their

Fig. 16. Schematic model of controls on backarc crustal accretion [26,27]. (A) At MORs surface lithospheric plates (solid light gray areas) separate (open arrows) and drive advection in the mantle (dashed stream lines). On rising above the (dry) solidus (heavy solid line) pressure release melting occurs until limited by the cool lithosphere above. Melt is transported to the spreading axis (fine dotted lines) and accretes the crust (dark gray). Melt-depleted mantle flows horizontally away with the separating lithospheric plates. Gray shading in the mantle above the solidus indicates increasing depletion of the residual mantle toward the surface. This figure follows [1]. (B) In subduction settings the motion of the slab (black arrows) drives corner flow advection in the mantle wedge (indicated by dashed stream lines with small arrows). Water released by the slab (which increases in concentration toward the volcanic front) and vertical advection induced by corner flow expand the volume of mantle above the solidus (indicated by heavy solid line). As mantle material is advected into the zone of hydration progressive partial melting occurs. Melt rises (fine dotted lines) and may form back-arc seamount chains (indicated by surface triangular shapes). Mantle is progressively depleted (indicated by darker gray shading) of a melt component toward the volcanic front (large surface triangular shape) and is advected toward the wedge corner and downward with the slab. For old and/or slowly subducted lithosphere, downward advection and slab cooling keep the solidus above the slab. This figure follows [66,70]. (C) When back-arc extension commences, the lithosphere rifts near the rheologically weak volcanic front. Hydrated mantle material in this region is advected upward into the stretching and thinning lithosphere, leading to high degrees of melting in the rift phase, unless slow subduction leads to significant mantle wedge cooling. (D) With increasing extension a seafloor spreading center is established near the volcanic front advecting highly hydrated mantle. As a consequence, an enhanced magmatic stage and thick crust (indicated by dark gray layer) result. (E) With continued spreading the extension axis separates from the volcanic front. Mantle hydration from the slab decreases and strongly melt-depleted mantle is varyingly mixed with ambient mantle as a result of corner flow and advection by the spreading center (indicated by closed streamline). These conditions result in diminished magmatism and thinner crust (indicated by thinner dark gray crustal layer). (F) Eventually, the backarc spreading system separates sufficiently from the volcanic front that it is not significantly affected by hydration, re-circulated melt-depleted mantle, and slab-derived geochemical components. Spreading centers now advect ambient MORB-source mantle and their crustal accretion characteristics are like MORs. 
lavas are LREE-depleted and MORB-like, with low water contents $(\sim 0.3 \%)$ and only very slight enrichments in LILE and depletions in $\mathrm{Ta}, \mathrm{Nb}$ $[35,37,44]$. With average ridge depths of $\sim 2300$ $\mathrm{m}$, the CLSC and MSC end-member $\mathrm{Fe} 8$ and $\mathrm{Na} 8$ values $(10.5 \%, 2.25 \%$, Fig. 10) fall on the global trend for MORB systematics, as do those of the east Scotia segments E5-E7 $(\sim 3500-4000 \mathrm{~m}, 8-$ $9.5 \%, 2.5-3.5 \%)[1,2]$.

Note, however, that BABB (group B) persist in the Manus Basin to distances of $250-300 \mathrm{~km}$ behind the New Britain island arc (Fig. 4) [37]. It is possible that the subducted fluids that modified the Manus mantle sources far from the modern arc were introduced by previous subduction of opposite polarity [61]. On the other hand, subduction components contribute to lavas from the east Scotia Basin spreading segments E2, E4, E8 and E9 at distances of $200-420 \mathrm{~km}$ behind the South Sandwich island arc (Fig. 8) $[43,44,48]$. We infer from these observations that back-arc spreading far behind island arcs should be MOR-like (Fig. $16 \mathrm{~F}$ ), although some small-scale, slab-derived, geochemical heterogeneity in the mantle may be long-lived. At $\sim 300-550 \mathrm{~km}$ behind the New Hebrides arc, the central spreading ridge of the North Fiji Basin is a modern example whose characteristics are in accord with this inference [79]. We predict that if the Mariana Trough continues to open, its spreading axis will migrate far enough from the volcanic front and slab effects to eventually accrete MOR-like crust.

\subsection{Mixing}

Mantle corner flow provides a ready physical mechanism for mixing MORB- and arc-like sources together, as the BAB geochemical data require. In addition to wedge-scale flow mixing, however, we envisage various smaller scales of mixing promoted by density and viscosity heterogeneities. Extraction of magma decreases the iron content of the residual mantle, making it more buoyant. If this dry residual mantle is re-hydrated by subduction components it will decrease in viscosity. The combination of the two effects above subducted slabs will tend to promote circulation away from slab-parallel streamlines, producing complex four-dimensional mixing within the mantle wedge. Such mixing will produce a 'marble cake' pattern of smaller-scale source heterogeneities, in addition to those produced by the firstorder corner flow, with increasing proportions of the MORB-source end-member further away from the subducted slab.

\section{Conclusion}

The composition of lavas from active BAB spreading centers include arc-like components characterized by low $\mathrm{Na} 8$, Ti8 and $\mathrm{Fe} 8$, and by high $\mathrm{H}_{2} \mathrm{O}(8)$ and $\mathrm{Ba} / \mathrm{La}$ (Figs. 10-15) and MORB-like end-members with the opposite traits. Between basins and, to a lesser extent, within each basin, the least hydrous compositions follow global MORB systematics that reflect their different extents and pressures of melting. The Lau and Manus mantle source regions are hotter than those of Mariana and Scotia, consistent with numerical models that induce greater wedge advection when subduction is faster. The MORB-type mantle sources are mixed with, and melt in proportion to the amount of, previously depleted $\mathrm{H}_{2} \mathrm{O}$-rich arc-type sources introduced by mantle wedge convection, to produce the range of observed compositions. The lower Fe8, Ti8 of $\mathrm{BABB}$ is not only the result of suppressed plagioclase crystallization relative to olivine, which produces higher Al8 and lower Fe8 [23,52], but also of their being melts of mixtures of MORB- and arc-like sources, the latter having undergone previous melting episodes.

Hydrous flux melting allows depleted mantle sources just behind the volcanic front to melt extensively (Fig. 16D), producing shallow spreading axes (e.g. VFR, SER, and VTZ). Flow of enriched mantle components around the ends of slabs may augment this process in transform-bounded backarcs such as the east Scotia Basin (segments E2 and E9). The re-circulation to the spreading axes of mantle previously depleted by both arc and spreading melt extraction (Fig. 16E) can explain the greater depths and thinner crust of the ELSC, SR, and Mariana Trough and the very depleted lavas of east Scotia segments E8/E9. The crust 
becomes MOR-like on the CLSC, MSC and east Scotia segments E5-E7, where the spreading axes, further away from the island arc and subducted slab, entrain dominantly fertile mantle (Fig. 16F).

\section{Acknowledgements}

We thank J. Sinton for providing a pre-publication manuscript and for discussions of Manus Basin geochemistry, P. Fryer, J. Pearce and R. Stern for unpublished analyses of Mariana Trough samples south of $15^{\circ} \mathrm{N}$, E. Stolper and S. Newman for unpublished analyses of water contents from east Scotia segment E2 lavas, and B. Cushman for help with Excel. These and other geochemists, particularly R. Arculus, S. DeBari, R. Batiza, J. Gill, J. Hawkins, F. Hochstaedter and C. Langmuir, have collaborated with us for many years. Constructive reviews and insightful questions by T. Plank and R. Stern are greatly appreciated. This work was funded by the US National Science Foundation MGG, ODP and MARGINS programs.[KF]

\section{References}

[1] C.H. Langmuir, E.M. Klein, T. Plank, Petrological systematics of mid-ocean ridge basalts: constraints on melt generation beneath ocean ridges, Am. Geophys. Un. Geophys. Monogr. 71 (1992) 183-280.

[2] E.M. Klein, C.H. Langmuir, Global correlations of ocean ridge basalt chemistry with axial depth and crustal thickness, J. Geophys. Res. 92 (1987) 8089-8115.

[3] E.M. Klein, C.H. Langmuir, Local versus global variations in ocean ridge basalt composition: A reply, J. Geophys. Res. 94 (1989) 4241-4252.

[4] Y. Niu, R. Batiza, An empirical method for calculating melt compositions produced beneath mid-ocean ridges: application for axis and off-axis (seamount) melting, J. Geophys. Res. 96 (1991) 21753-21777.

[5] Y. Niu, R. Batiza, Chemical variation trends at fast and slow spreading mid-ocean ridges, J. Geophys. Res. 98 (1993) 788-7902.

[6] J.P. Brodholt, R. Batiza, Global systematics of unaveraged mid-ocean ridge basalt compositions: Comment on 'Global correlations of ocean ridge basalt chemistry with axial depth and crustal thickness' by E.M. Klein and C.H. Langmuir, J. Geophys. Res. 94 (1989) 4231-4239.

[7] Y. Shen, D.W. Forsyth, Geochemical constraints on ini- tial and final depths of melting beneath mid-ocean ridges, J. Geophys. Res. 100 (1995) 2211-2237.

[8] Y. Niu, R. Hékinian, Spreading rate dependence of the extent of mantle melting beneath ocean ridges, Nature 385 (1997) 326-329.

[9] Y. Niu, D. Bideau, R. Hekinian, R. Batiza, Mantle compositional control on the extent of mantle melting, crust production, gravity anomaly, ridge morphology, and ridge segmentation: a case study at the Mid-Atlantic Ridge $33-35^{\circ}$ N, Earth Planet. Sci. Lett. 186 (2001) 383 399.

[10] M.O. Garcia, N.W.K. Liu, D. Muenow, Volatiles in submarine volcanic rocks from the Mariana Island arc and trough, Geochim. Cosmochim. Acta 43 (1979) 305-312.

[11] I.S.E. Charmichael, The redox state of basic and silicic magmas: a reflection of their source regions?, Contrib. Mineral. Petrol. 106 (1991) 129-141.

[12] P. Ulmer, Partial melting in the mantle wedge-the role of $\mathrm{H}_{2} \mathrm{O}$ in the genesis of mantle-derived 'arc related' magmas, Phys. Earth Planet. Inter. 127 (2001) 215-232.

[13] P. Michael, Regionally distinctive sources of depleted MORB; evidence from trace elements and $\mathrm{H}_{2} \mathrm{O}$, Earth Planet. Sci. Lett. 131 (1995) 301-320.

[14] A.V. Sobolov, M. Chaussidon, $\mathrm{H}_{2} \mathrm{O}$ concentrations in primary melts from supra-subduction zones and midocean ridges: implications for $\mathrm{H}_{2} \mathrm{O}$ storage and recycling in the mantle, Earth Planet. Sci. Lett. 137 (1996) 45-55.

[15] L.V. Danyushevsky, The effect of small amounts of $\mathrm{H}_{2} \mathrm{O}$ on crystallisation of mid-ocean ridge and backarc basin magmas, J. Volcanol. Geotherm. Res. 110 (2001) 265-280.

[16] A.L. Jacques, D.H. Green, Anhydrous melting of peridotite at $0-15 \mathrm{~kb}$ pressure and the genesis of tholeiitic basalts, Contrib. Mineral. Petrol. 73 (1980) 287-310.

[17] T.J. Falloon, D.H. Green, C.J. Hatton, K.L. Harris, Anhydrous partial melting of a fertile and depleted peridotite from $2-30 \mathrm{~kb}$ and applications to basalt petrogenesis, J. Petrol. 29 (1988) 1257-1282.

[18] K. Hirose, I. Kushiro, Partial melting of dry peridotites at high pressures: determination of compositions of melts segregated from peridotite using aggregates of diamond, Earth Planet. Sci. Lett. 90 (1993) 477-489.

[19] K. Hirose, T. Kawamoto, Hydrous partial melting of lherzolite at $1 \mathrm{GPa}$ - the effect of $\mathrm{H}_{2} \mathrm{O}$ on the genesis of basaltic magma, Earth Planet. Sci. Lett. 133 (1995) 463 473 .

[20] G.A. Gaetani, T.L. Grove, The influence of water on melting of mantle peridotite, Contrib. Mineral. Petrol. 131 (1998) 323-346.

[21] T.J. Falloon, L.V. Danyushevsky, Melting of refractory mantle at 1.5, 2.0 and $2.5 \mathrm{GPa}$ under anhydrous and $\mathrm{H}_{2} \mathrm{O}$-undersaturated conditions: implications for the petrogenesis of high-Ca boninites and the influence of subduction components on mantle melting, J. Petrol. 41 (2000) 257-283.

[22] T.H. Green, A.E. Ringwood, Crystallisation of basalt and andesite under high pressure hydrous conditions, Earth Planet. Sci. Lett. 3 (1968) 481-489. 
[23] P. Fryer, J.M. Sinton, J.A. Philpotts, Basaltic glasses from the Mariana Trough, in: DSDP Init. Repts. 60 (1981) 601-609.

[24] P.J. Michael, R.L. Chase, The influence of primary magma composition, $\mathrm{H}_{2} \mathrm{O}$ and pressure on mid-ocean ridge basalt differentiation, Contrib. Mineral. Petrol. 96 (1987) 245-263.

[25] T.W. Sisson, T.L. Grove, Experimental investigation of the role of $\mathrm{H}_{2} \mathrm{O}$ in calc-alkaline differentiation and subduction zone magmatism, Contrib. Mineral. Petrol. 113 (1993) 143-166.

[26] F. Martinez, B. Taylor, Mantle wedge control on backarc crustal accretion, Nature 416 (2002) 417-420.

[27] F. Martinez, B. Taylor, Controls on backarc crustal accretion: Insights from the Lau, Manus and Mariana basins, in: R. Larter, P. Leat (Eds.), Intra-Oceanic Subduction Systems: Tectonic and Magmatic Processes, Geol. Soc. London Spec. Publ., 2003.

[28] X. Boespflug, L. Dosso, H. Bougault, W.J. Pegram, J.L. Joron, Trace element and isotopic $(\mathrm{Sr}, \mathrm{Nd})$ geochemistry of volcanic rocks from the Lau Basin, Geol. Jb. 92 (1990) 503-516.

[29] G. Frenzel, R. Muhe, P. Stoffers, Petrology of the volcanic rocks from the Lau Basin, southwest Pacific, Geol. Jb. 92 (1990) 395-479.

[30] G. Sunkel, Origin of petrological and geochemical variations of Lau Basin lavas (SW Pacific), Mar. Min. 9 (1990) 205-234.

[31] T.J. Falloon, A. Malahoff, L.P. Zonenshain, Y. Bogdanov, Petrology and geochemistry of backarc basin basalts from Lau Basin spreading ridges at 15,18 , and $19^{\circ} \mathrm{S}$, Mineral. Petrol. 47 (1992) 1-35.

[32] L.V. Danyushevsky, T.J. Falloon, A.V. Sobolev, A.J. Crawford, M. Carroll, R.C. Price, The $\mathrm{H}_{2} \mathrm{O}$ content of basalt glasses from Southwest Pacific back-arc basins, Earth Planet. Sci. Lett. 117 (1993) 347-362.

[33] J.W. Hawkins, The Geology of the Lau Basin, in: B. Taylor (Ed.), Backarc Basins: Tectonics and Magmatism, Plenum Press, New York, 1995, pp. 63-138.

[34] J.A. Pearce, M. Ernewein, S.H. Bloomer, L.M. Parson, B.J. Murton, L.E. Johnson, Geochemistry of Lau Basin volcanic rocks: influence of ridge segmentation and arc proximity, Geol. Soc. London Spec. Publ. 81 (1995) 53-75.

[35] D.W. Peate, T.F. Kokfelt, C.J. Hawkesworth, P.W.V. Calsteren, J.M. Hergt, J.A. Pearce, U-series isotope data on Lau Basin glasses: the role of subduction-related fluids during melt generation in back-arc basins, J. Petrol. 42 (2001) 1449-1470.

[36] A.J.R. Kent, D.W. Peate, S. Newman, E.M. Stolper, J.A. Pearce, Chlorine in submarine glasses from the Lau Basin: seawater contamination and constraints on the composition of slab-derived fluids, Earth Planet. Sci. Lett. 202 (2002) 361-377.

[37] J.M. Sinton, L.L. Ford, B. Chappell, M. McCulloch, Magma genesis and mantle heterogeneity in the Manus back-arc basin, Papua New Guinea, J. Petrol. 44 (2003) 159-195.
[38] J.W. Hawkins, P.F. Lonsdale, J.D. Macdougall, A.M. Volpe, Petrology of the axial ridge of the Mariana Trough backarc spreading center, Earth Planet. Sci. Lett. 100 (1990) 226-250.

[39] R.J. Stern, P.-N. Lin, J.D. Morris, M.C. Jackson, P. Fryer, S.H. Bloomer, E. Ito, Enriched back-arc basin basalts from the northern Mariana Trough: implications for the magmatic evolution of back-arc basins, Earth Planet. Sci. Lett. 100 (1990) 210-225.

[40] E. Stolper, S. Newman, The role of water in the petrogenesis of Mariana trough magmas, Earth Planet. Sci. Lett. 121 (1994) 293-325.

[41] R.F. Gribble, R.J. Stern, S.H. Bloomer, D. Stuben, T. O'Hearn, S. Newman, MORB mantle and subduction components interact to generate basalts in the southern Mariana Trough back-arc basin, Geochim. Cosmochim. Acta 60 (1996) 2153-2166.

[42] R.F. Gribble, R.J. Stern, S. Newman, S.H. Bloomer, T. O'Hearn, Chemical and isotopic composition of lavas from the northern Mariana Trough: implications for magmagenesis in back-arc basins, J. Petrol. 39 (1998) $125-154$.

[43] P.T. Leat, R.A. Livermore, I.L. Millar, J.A. Pearce, Magma supply in back-arc spreading centre segment E2, East Scotia Ridge, J. Petrol. 41 (2000) 845-866.

[44] S. Fretzdorff, R.A. Livermore, C.W. Devey, P.T. Leat, P. Stoffers, Petrogenesis of the Back-arc East Scotia Ridge, South Atlantic Ocean, J. Petrol. 43 (2002) 1435-1467.

[45] K.E. Zellmer, B. Taylor, A three-plate kinematic model for Lau Basin opening, Geochem. Geophys. Geosyst. 2 (2001) 2000GC000106.

[46] F. Martinez, B. Taylor, Backarc spreading, rifting, and microplate rotation between transform faults in the Manus Basin, Mar. Geophys. Res. 18 (1996) 203-224.

[47] P. Fryer, Geology of the Mariana Trough, in: B. Taylor (Ed.), Backarc Basins: Tectonics and Magmatism, Plenum Press, New York, 1995, pp. 237-279.

[48] R. Livermore, Back-arc spreading and mantle flow in the east Scotia Sea, in: R. Larter, P. Leat (Eds.), Intra-Oceanic Subduction Systems: Tectonic and Magmatic Processes, Geol. Soc. London Spec. Publ., 2003.

[49] T. Plank, C.H. Langmuir, Effects of the melting regime on the composition of the oceanic crust, J. Geophys. Res. 97 (1992) 19749-19770.

[50] P. Tregoning, Plate kinematics in the western Pacific derived from geodetic observations, J. Geophys. Res. B 107 (2002) 2001JB000406.

[51] T. Kato, J. Beavan, T. Matsushima, Y. Kotake, J. Camacho, S. Nakao, Geodetic evidence of back arc spreading in the Mariana Trough, Geophys. Res. Lett. (2003).

[52] J.M. Sinton, P. Fryer, Mariana Trough lavas from $18^{\circ} \mathrm{N}$ : Implications for the origin of backarc basin basalts, J. Geophys. Res. 92 (1987) 12782-12802.

[53] A.M. Volpe, J.D. Macdougall, J.W. Hawkins, Mariana Trough basalts (MTB): trace element and $\mathrm{Sr}-\mathrm{Nd}$ isotopic evidence for mixing between MORB-like and Arc-like melts, Earth Planet. Sci. Lett. 82 (1987) 241-254. 
[54] D.A. Wood, N.G. Marsh, J. Tarney, J.L. Joron, P. Fryer, M. Treuil, Geochemistry of igneous rocks recovered from a transect across the Mariana Trough, arc and trench, Sites 453-461, DSDP Init. Repts. 60 (1981) 611-646.

[55] R. Livermore, A. Cunningham, L. Vanneste, R. Larter, Subduction influence on magma supply at the East Scotia Ridge, Earth Planet. Sci. Lett. 150 (1997) 261-275.

[56] N.J. Bruguier, R.A. Livermore, Enhanced magma supply at the southern East Scotia Ridge: evidence for mantle flow around the subducting slab?, Earth Planet. Sci. Lett. 191 (2001) 129-144.

[57] M. Bevis, F.W. Taylor, B.E. Schutz, J. Recy, B.L. Isacks, S. Helu, R. Singh, E. Kendrick, J. Stowell, B. Taylor, S. Calmant, Geodetic observations of very rapid convergence and back-arc extension at the Tonga arc, Nature 374 (1995) 249-251.

[58] J.H. Davies, D.J. Stevenson, Physical model of source region of subduction zone volcanics, J. Geophys. Res. 97 (1992) 2037-2070.

[59] S.M. Peacock, Thermal and petrological structure of subduction zones, Am. Geophys. Un. Geophys. Monogr. 96 (1996) 119-133.

[60] A. Ewart, C.J. Hakesworth, The Pleistocene-Recent Tonga-Kermadec arc lavas: Interpretation of new isotopic and rare earth data in terms of a depleted mantle source model, J. Petrol. 28 (1987) 495-530.

[61] J.D. Woodhead, S.M. Eggins, R.W. Johnson, Magma genesis in the New Britain island arc: further insights into melting and mass transfer processes, J. Petrol. 39 (1998) 1641-1668.

[62] J.A. Pearce, P.E. Baker, P.K. Harvey, I.W. Luff, Geochemical evidence for subduction fluxes, mantle melting and fractional crystallization beneath the South Sandwich island arc, J. Petrol. 36 (1995) 1073-1109.

[63] A.M. Volpe, J.D. Macdougall, G.W. Lugmair, J.W. Hawkins, P. Lonsdale, Fine-scale isotopic variation in Mariana Trough basalts: evidence for heterogeneity and a recycled component in backarc basin mantle, Earth Planet. Sci. Lett. 100 (1990) 251-264.

[64] P.D. Asimov, C.H. Langmuir, The importance of water to oceanic mantle melting regimes, Nature 421 (2003) 815-820.

[65] J.A. Pearce, I.J. Parkinson, Trace element models for mantle melting: application to volcanic arc petrogenesis, Geol. Soc. Spec. Publ. 76 (1993) 373-403.

[66] A.G. Hochstaedter, P. Kepezhinskas, M. Defant, M. Drummond, A. Koloskov, Insights into the volcanic arc mantle wedge from magnesian lavas from the Kamchatka arc, J. Geophys. Res. 101 (1996) 697-712.
[67] A. Ewart, K.D. Collerson, M. Regelous, J.I. Wendt, Y. Niu, Geochemical evolution within the Tonga-KermadecLau Arc-Back-arc system: the role of varying mantle wedge composition in space and time, J. Petrol. 39 (1998) 331-368.

[68] J. Woodhead, S. Eggins, J. Gamble, High field strength and transition element systematics in island arc and backarc basin basalts: Evidence for multiphase melt extraction and a depleted mantle wedge, Earth Planet. Sci. Lett. 114 (1993) 491-504.

[69] A.G. Hochstaedter, J.B. Gill, B. Taylor, O. Ishizuka, M. Yuasa, S. Morita, Across-arc geochemical trends in the Izu-Bonin arc: Constraints on source composition and mantle melting, J. Geophys. Res. 105 (2000) 495512.

[70] A. Hochstaedter, J. Gill, R. Peters, P. Broughton, P. Holden, B. Taylor, Across-arc geochemical trends in the IzuBonin arc: Contributions from the subducting slab, Geochem. Geophys. Geosyst. 2 (2001) 2000 GC000105.

[71] N.M. Ribe, Mantle flow induced by back arc spreading, Geophys. J. Int. 98 (1989) 85-91.

[72] S. Turner, C. Hawkesworth, Using geochemistry to map mantle flow beneath the Lau Basin, Geology 26 (1998) 1019-1022.

[73] P. Fryer, B. Taylor, C.H. Langmuir, A.G. Hochstaedter, Petrology and geochemistry of lavas from the Sumisu and Torishima backarc rifts, Earth Planet. Sci. Lett. 100 (1990) 161-178.

[74] A.G. Hochstaedter, J.B. Gill, M. Kusakabe, S. Newman, M. Pringle, B. Taylor, P. Fryer, Volcanism in the Sumisu Rift. I. Major element, volatile, and stable isotope geochemistry, Earth Planet. Sci. Lett. 100 (1990) 179-194.

[75] J.W. Hawkins, J.F. Allan, Petrologic evolution of the Lau Basin, sites 834-839, Proc. ODP Sci. Results 135 (1994) 427-470.

[76] B. Taylor, Rifting and the volcanic-tectonic evolution of the Izu-Bonin-Mariana arc, Proc. ODP Sci. Results 126 (1992) 627-651.

[77] B. Taylor, G.D. Karner, On the evolution of marginal basins, Rev. Geophys. Space Phys. 21 (1983) 1727 1741.

[78] Y. Tamura, Y. Tatsumi, D. Zhao, Y. Kido, H. Shukuno, Hot fingers in the mantle wedge: new insights into magma genesis in subduction zones, Earth Planet. Sci. Lett. 197 (2002) 105-116.

[79] J.-M. Auzende, B. Pelletier, J.-P. Eissen, The North Fiji Basin: Geology, structure and geodynamic evolution, in: B. Taylor (Ed.), Backarc Basins: Tectonics and Magmatism, Plenum Press, New York, 1995, pp. 139-175. 